\title{
Islamic Values in the Annual Reports of the Shariah Bank to Create a Sharia Value-Added
}

\author{
Rediyanto Putra* ${ }^{1}$ and Rahma Rina Wijayanti ${ }^{2}$
}

AFFILIATION:
${ }^{1}$ Department of Accounting,
Universitas Negeri Surabaya, East
Java, Indonesia.
${ }^{2}$ Department of Public Sector
Accounting, Politeknik Negeri
Jember, East Java, Indonesia.

\section{*CORRESPONDENCE:}

rediputra.rp@gmail.com

THIS ARTICLE IS AVALILABLE IN:

http://journal.umy.ac.id/index.php/ai

DOI: 10.18196/jai.2101139

\section{CITATION:}

Putra, R., \& Wijayanti, R. R. (2020). Islamic Values in the Annual Reports of the Shariah Bank to Create a Sharia Value-Added. Journal of Accounting and Investment, 21(1), 90-113.

\section{ARTICLE HISTORY}

\section{Received:}

16 Dec 2018

Reviewed:

27 Jan 2019

05 June 2019

Revised:

05 Mar 2019

12 Oct 2019

Accepted:

22 Nov 2019

\begin{abstract}
:
Research Aim: This study aims to examine, understand, and prove the embodiment of Islamic values in the annual report of Sharia Banks. The results of this study are expected to provide information or data to all parties regarding the layout and Islamic values in the Sharia Banks' annual report, which can be a form of a real differentiator between Sharia Banks and conventional banks if viewed in terms of the content of the annual report.
\end{abstract}

Design/Methodology/Approach: The interpretive method in this study is suitable for research purposes that are not intended to perform hypothesis testing but to do an interpretation of research data. The interpretive method used in this research is to analyze the data by using semiotic analysis. Differential semiotic analysis is an analysis of data that focuses on meaning and sign. Semiotic analysis of the annual sharia bank report is carried out on the narrative texts on the annual report. Semiotic analysis in this study is based on Charles Sanders Pierce's semiotic analysis which uses the triangles of meaning.

Research findings: The results of the study showed that the annual reports of Muamalat Bank from 2012 to 2016 had indicated Islamic values. Islamic values were found most frequently in the annual report of Muamalat Bank from 2014 to 2016. The Islamic values in the annual reports of Muamalat Bank were included in the Sharia Supervisory Board Report, the Board of Commissioner Report, the Board of Directors, corporate governance information, and information related to Corporate Social Responsibility (CSR). Thus, the presence of Islamic values in the annual reports of Muamalat Bank can create the sharia value added to the company.

Theoretical contribution/Originality: The results of this study have contributed to the application of the Shari'ah Enterprise Theory (SET). The existence of the application of Islamic values in the financial statements of Bank Muamalat shows that Bank Muamalat is not only responsible for its business activities to humans (investors) but also to God.

Practitioner/Policy implication: The results of this study indicate that Bank Muamalat must continue to maintain the existence of Islamic values in operational activities that are presented in its annual report. This is due to the fact that Bank Muamalat's operational activities are truly in accordance with Islamic law.

Research limitation/Implication: The Islamic values were found most frequently in the annual reports of Muamalat Bank from 2014 to 2016. A good practice of Islamic values is finally expected to result in the meaningful added value of sharia. The limitations in this article that are the number of the theory and methodologies related to the phenomenon of Islamic values on the disclosure of information in the annual reports is still limited. So, further researches will be necessary to find another theory and develop methodologies to investigate the Islamic values represented in the annual report of sharia banking.

Key Words: Annual Report; Islamic Value; Sharia Added Value. 


\section{Introduction}

A bank is a business entity that serves as a financial channel in a country. Indonesian Law no. 7 the year 1992 states that the bank duty is collecting funds from the community in the form of deposits and distributing them back to the community. Thus, the bank is a business entity that is very important in supporting the economy of a country's society. Banks in Indonesia at this time have been doing two types of principles namely the conventional principles and sharia principles. Sharia Banks in Indonesia have significantly grown because many parties need financial services that are embodied with Islamic principles. These principles exist in Indonesian society because Indonesia is a country with Moslems as the majority of the population. Islamic banks have finally appeared to meet the needs for the Indonesian society of the financial services by following the principles of Islam. Act No. 21 the year 2008 explains that Shari'ah Bank is a bank that performs operational activities based on the sharia principles that include the principles of Islam in legislation, and the fatwa issued by the authorized institution.

The Shari'ah banking system has existed since the beginning of Islam 1,400 years ago. Alharbi (2015) states that historical books written in the early years of Islam show that during the first century of Islam (AD 600), there were some forms of banking activity similar to modern banking transactions which revealed that Al-Zubair bin Al- Layman, one of the most famous figures in Islam, accepted deposits from people as loans and invested the money and returned the deposit to the owner. It is also written by several contemporary scholars such as Chachi (2005) which shows that there are bankers called sarraffeen or sayarifah (single sarraf) or jahabidhah (banks called dawawin aljahabidhah) in the Islamic Empire.

The development of shariah bank in Indonesia has been indicated since the year 1991 marked with the advent of PT Bank Muamalat Indonesia Tbk. At that time, Muamalat Bank was the only Shari'ah bank in Indonesia. However, at the time there were no rules governing sharia principles for banking. Sharia banking legislation recently appeared in 1998 with the promulgation of Act No. 10 the year 1998. This Act has renewed the law No. 7 of the year 1992 by adding an understanding, principles and Shariah-compliant financing. The development of Islamic banks currently has experienced a significant spike. This is demonstrated by the increasing number of Islamic banks in Indonesia until 2016. Figure 1 shows the number of Islamic banking in Indonesia from 2091 to 2016.

Figure 1 shows that the General Shariah Bank, Shariah Business Unit, and Shariah Rural Bank in Indonesia have many offices until January 2017. Based on the graph the growth rate of sharia over the 25 years (1991-2016) was substantial with the number of Sharia Banking as many as 717 sharia banking including BUS, UUS, and BPRS. Thus, sharia banking in Indonesia gained the trust of the people of Indonesia. Figure 1 shows that the number of sharia banking in Indonesia was predominated by General Shariah Bank, Sharia Business Unit (UUS), and Sharia Rural Bank (BPRS), respectively. 
Putra \& Wijayanti

Islamic Values in the Annual Reports of the Shariah Bank ...

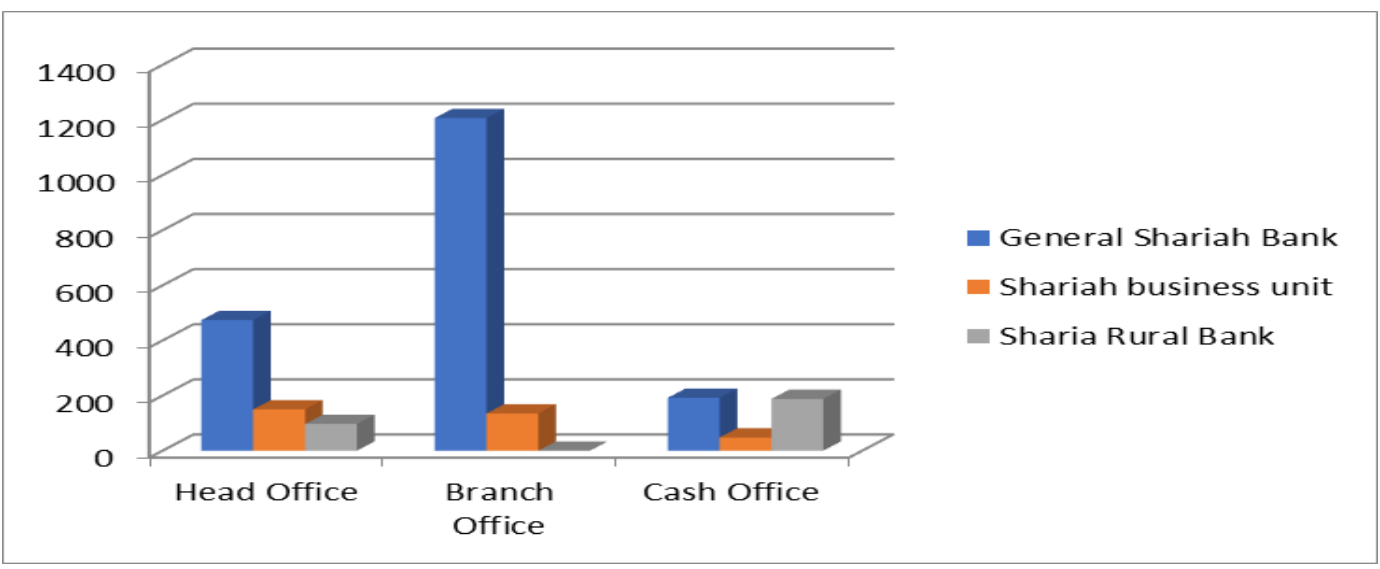

Figure 1 Number of Sharia Banking

Source: Financial Services Authority's Shariah Banking Statistic 2017

Shariah Banks in Indonesia, in carrying out operational activities, have different characteristics from the conventional banks due to the applied sharia principles. Shariah principles applied by foreign Islamic banking caused interest (riba) in Shariah-compliant transactions. Islamic banks use the system of profit-sharing in more operational activities. Paramitasari (2012) states that the system can provide an alternative for the results in the banking system to create benefits for the community and the banking institutions, justice when conducting transactions, ethical investments, prioritizing the value of togetherness and brotherhood, and avoiding speculation. The process of Islamic banking operations is different from conventional banks causing the need for a form of supervision of law enforcement authorities. Authorities responsible for overseeing the operational activity of the bank is the Board of Trustees of Islamic Sharia (DPS). DPS has the task of supervising and advising the management to ensure that the banking operations are in line with the Sharia principles (Nugraheni \& Yuliani, 2012). Therefore, at the end of each year, the Sharia Supervisory Board will issue the report simultaneously with the external auditor's audit results. This annual report aims to guarantee the users of financial statements to ensure that the bank has complied with the principles of the Islamic Sharia in all transactions.

Sharia bank annual report is a useful source of information as a form of accountability for stakeholders. The annual report of sharia banking differs from the annual report published by conventional banking. This is because the Islamic sharia principles are applied in sharia banking. The annual report of sharia banking should comply with the explanation of Shariah Enterprise Theory (SET). SET explains that the responsibility of the Shariah entity must be made to God, humans, and nature as stakeholders (Triyuwono, 2007). Thus, Sharia Banks must be able to perform all transactions in compliance with the principles of Islamic sharia in order to be accountable to stakeholders.

Shari'ah bank annual reports need to maintain Islamic values because shariah banks carry out transactions based on a paradigm that the universe is God's creation which is a trust and a means of happiness and prosperity for all humanity (KDPPLKS, 2007). Therefore, the annual report of sharia banks must have Islamic values that indicate the 
presence of a divine element as a good parameter for business activity. In addition, annual reports like those of shari'ah needs to have Islamic values because a shari'ah bank has five characteristics derived from the Islamic values, namely (1) basic values and philosophy containing the principle of rabbaniyah because it refers to the objectives of Islam itself, (2) products and services that are interest-free containing insaniyah values, (3) agreements that are only allowed according to the Islamic laws comprising the values of clarity/ablution, (4) focus on social development and goals comprising the universal values applies to all aspects of life and (5) the existence of a sharia supervisory board (DPS) (Hudaib (2007) in Prasetyaningsih and Prakosa (2010). These five characteristics are references to standards by AAOIFI and are themes that are translated into Islamic corporate identity.

The annual reports of sharia banking in Indonesia might not reflect the values of sharia principles. This is evident in some previous research results from Prasetyaningsih and Prakosa (2010), Paramitasari (2012), Sukardi and Wijaya (2013), Yuniwijayanti (2014), Pratiwi and Chariri (2015). Some results of these studies are inconsistent with the presence of Islamic values in the annual report of shari'ah banks in this present study. Paramitasari (2012) research results indicate that the annual shari'ah bank report has not fully demonstrated the embodiment of Islamic values. Paramitasari (2012) explained that the dimensions of the products and services from two of the three investigated companies might not provide information related to the approval of Shari'ah Supervisory Board. This caused wavering in terms of the level of halal products and services provided. However, some previous studies indicated that the annual report of shari'ah banks reflected the existence of Islamic values. Prasetyaningsih and Prakosa (2010) and Petrus and Wijaya (2013) also add about a lack of attention to the Islamic banking dimensions of zakat, alms, and loan of virtue indicating the identity of ethical annual reports on Islamic banking. However, the Yuniwijayanti and Praktiwi and Chariri (2015) shows different results. The research stated that Sharia banking annual report had the value of da'wah, more than merely dealing with the economic reality. Therefore, research related to the search for Islamic values in the annual report on syariah bank in Indonesia is still needed.

Researches related to Islamic value in the annual report on shariah banks are required based on two reasons. The first is the inconsistencies in the results of the previous researches. Secondly, the previous researches (Prasetyaningsih and Prakosa, 2010; Paramitasari, 2012; He and Wijaya, 2013) investigated the Islamic values in the annual reports by using values indexing, while Pratiwi and Chariri (2015) investigated through the photos contained in the annual reports of shariah banks without doing the interpretation on the sentences or information on the annual reports to give the maximum results. Third, the research of Yuniwijayanti (2014) was using semiotic analytical methods to know the Islamic values on the annual report of Mandiri Syariah Bank with a shorter period; one year. Therefore, this research offers meaning-related research by using semiotic analysis on Islamic banking annual reports with a longer period in order to get more credible data. Research like this is necessary as an evaluation tool for the annual report of shariah banks in Indonesia. 
This study aims to examine, understand, and prove the embodiment of Islamic values in the annual report of Sharia Banks. The results of this study are expected to provide information or data to all parties regarding the layout and Islamic values in the Sharia Banks' annual report, which can be a form of a real differentiator between Sharia Banks and conventional banks if viewed in terms of the content of the annual report. This research used annual reports of Bank Muamalat Tbk from 2012 to 2016 as the research object. Bank Muamalat Tbk was chosen in this research because Bank Muamalat Tbk is the first syariah bank in Indonesia. In addition, Bank Mumalat Tbk in 2017 was awarded as the best sharia bank in Indonesia with two awards at the same time: the first rank for the category of assets of 25 trillion and above and the first rank of TBK Indonesia-IV Company Award 2017 (APTI-IV-2017) (www.bankmuamalat.co.id). The next sections of this article address the theoretical studies, research methods, discussion, and conclusion.

\section{Literature Review}

Shariah enterprise theory arises because of the values of capitalism in enterprise theory. Enterprise theory is then developed to be more suitable for use by the sharia entities including sharia banks. The development of enterprise theory is then called shariah enterprise theory. Shariah enterprise theory (SET) further balances the value of egoistic (masculine) with alturistic (feminim), material value (masculine) with spiritual value (feminism), and so on (Triyuwono, 2007). Balancing the values in shariah enterprise theory leads to the emergence of concerns for all stakeholders. The stakeholders refer to God, man, and nature. Therefore, every sharia entity, including sharia banks, in carrying out its operational activities must be accountable to God, humans, and nature.

SET has a difference that accentuates theories that exist in other accounting that is related to stakeholders. The most important stakeholder in the SET is God. Triyuwono (2007) stated that SET should foster awareness of God for its users which ultimately obliges sunnatullah as the basis of sharia construction. The SET then makes man a second stakeholder after God. Human stakeholders in the SET itself are divided into two namely direct stakeholders and indirect stakeholders. Triyuwono (2007) states that direct stakeholders are the parties that contribute directly to the company, while indirect stakeholders are parties that do not contribute at all to the company. Therefore, SET does apply a balanced form that causes a form of concern. The last stakeholder in the SET is nature. SET makes nature a stakeholder because the existence of a company is because of the energy, raw materials, and others provided by nature (Triyuwono, 2007). The form of contribution that is given as a return to nature can be done by preserving nature.

The notion of Shariah Enterprise Theory (SET) discloses that humans are not the main stakeholders. The main stakeholder for SET is God, so the ultimate responsibility is for God. Thus, every syariah organization including a sharia bank must take responsibility for its operational activities to God. Triyuwono (2007) declares God to be the major stakeholder in SET because humans and the universe will eventually return to God. 


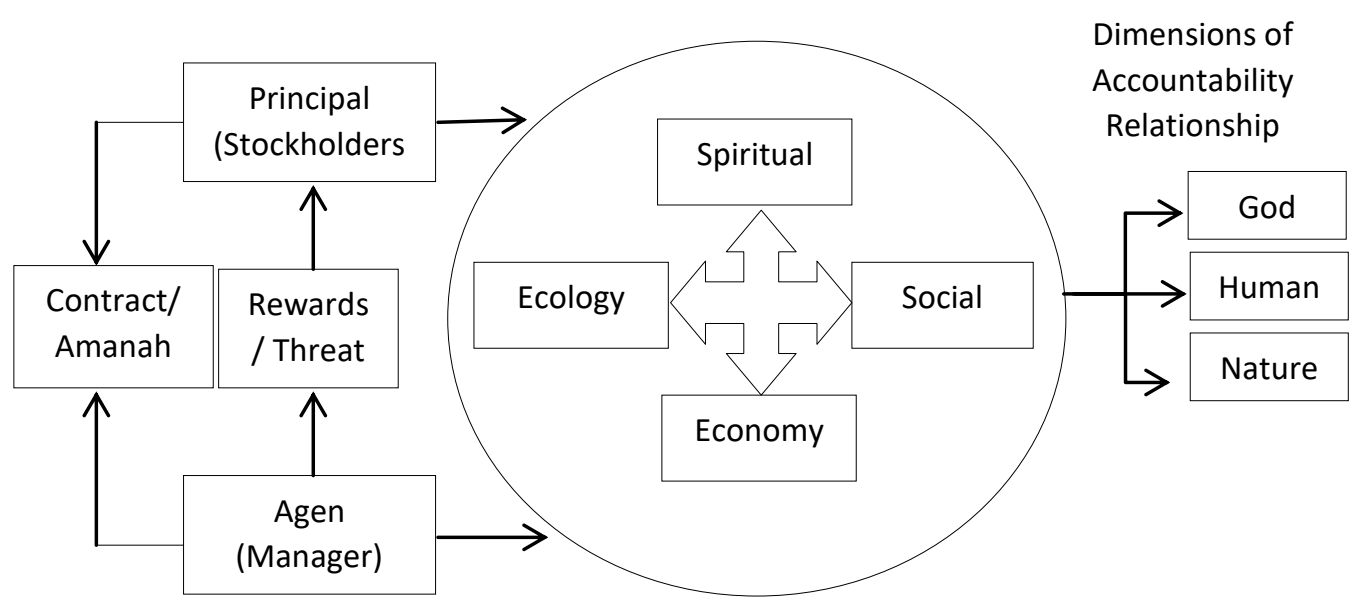

Figure 2 Accountability Forms of Shariah Enterprise Theory (SET)

Source: Amerieska, Irianto, \& Affandy (2012)

Therefore, man must obey God by carrying out all activities by following what is commanded by God. The sharia bank accountability form based on SET is shown in Figure 2.

Banks are financial institutions that play an important role in the process of collection and channeling of funds. Law no. 7 of 1992 states that the bank is a business entity that has a duty to collect funds from the community in the form of deposits and distribute them back to the community. Banks in Indonesia in carrying out its operational activities adopt two types of conventional principles and Shariah principles. Banks that run their operations based on sharia principles are called sharia banks. Law No. 21 the year 2008 states that sharia bank is a bank conducting business activities based on sharia principles; the Islamic principles from the Law and fatwa issued by the institution authorized in the determination of fatwa in the field of sharia.

Sharia principles embraced by sharia banking ultimately result in operational activities undertaken by the banking system. Sharia banking has a significant difference in its operational activities when compared to conventional banks. Those undertaken by sharia banks must conform to Islamic values. Ascarya and Yumanita (2005:4) state that the operational activities of sharia banks should be based on the following principles:

a. Operational activities shall be free of interest (usury)

b. Operational activities should be free of speculative non-productive such as gambling (masyir)

c. Operational activities should be free of uncertainty and doubt (gharar)

d. Operational activities should be free of damaged or invalid (bathil)

e. Operational activities only do financing on something kosher. 
Islamic Values in the Annual Reports of the Shariah Bank ...

Table 1 Differences in Sharia and Conventional Banking Characteristics

\begin{tabular}{|c|c|c|}
\hline No. & Syariah Banking & Conventional Banking \\
\hline 1 & Halal investment & Investment is halal and haram \\
\hline 2 & $\begin{array}{l}\text { Using the principle of profit- } \\
\text { sharing, buying and selling }\end{array}$ & Using the device of interest (riba) \\
\hline 3 & Oriented to profit and falah & Oriented only on profit \\
\hline 4 & $\begin{array}{l}\text { Using the principle of } \\
\text { partnership }\end{array}$ & Using the debtor-creditor principle \\
\hline 5 & $\begin{array}{l}\text { The collection and distribution } \\
\text { of funds must comply with the } \\
\text { fatwa of the Sharia Supervisory } \\
\text { Board }\end{array}$ & Does not have a similar board \\
\hline
\end{tabular}

Source: Antonio (2001) in Hafied dan Nasir (2013)

It can be concluded that sharia banking prioritizes the principle of halal, partnership, and avoids usury in carrying out its operational activities. Sharia principles embraced by sharia banking ultimately lead to different characteristics between sharia banks and conventional banks. The different characteristics of Sharia Banks with conventional banks are as follows table 1.

A brief explanation of table 1 shows that Islamic banking activities are in accordance with the Islamic Shariah. Thus, Islamic banking has been trusted to be more careful in conducting its operational activities to fit properly.

This study aims to conduct an assessment of the Islamic values presented in the annual reports of Bank Muamalat Tbk. Researches on a similar theme have previously been done. Table 2 presents a brief summary of the results of the previous researches.

Table 2 shows that the results of the previous studies that have been done indicate insufficiency in Sharia Banks. The insufficiency includes operational activities or disclosure reports. This study aims to reexamine and assess the reality of Islamic values represented in the annual reports of Bank Muamalat Tbk. This study is based on research results from Yuniwijayanti (2014) and Pratiwi and Chariri (2015). 
Putra \& Wijayanti

Islamic Values in the Annual Reports of the Shariah Bank ...

Table 2 Study of Islamic Values on the Annual Report

\begin{tabular}{|c|c|c|c|}
\hline Name & Research Object & Method & Result \\
\hline $\begin{array}{l}\text { Muhammad } \\
\text { (2009) }\end{array}$ & $\begin{array}{l}\text { The annual report of } \\
\text { sharia banking from } \\
\text { four countries } \\
\text { namely Pakistan, } \\
\text { Malaysia, Bahrain, } \\
\text { and Indonesia in } \\
2007\end{array}$ & $\begin{array}{l}\text { The evaluative } \\
\text { analysis includes } \\
\text { analysis of report } \\
\text { types and records } \\
\text { presented and } \\
\text { disclosed in each } \\
\text { report }\end{array}$ & $\begin{array}{l}\text { The results show that Sharia Banking has different } \\
\text { characteristics in presenting and disclosing financial } \\
\text { performance and non-financial activities. Bahrain } \\
\text { and Indonesia tend to follow the standards of } \\
\text { AAOIFI. However, Pakistan and Malaysia are more } \\
\text { inclined not to follow the accounting standards of } \\
\text { AAOIFI related to financial statements. However, } \\
\text { overall shariah banking from all four countries has } \\
\text { financial statements that can complement one } \\
\text { another to the ideal model. }\end{array}$ \\
\hline Afdal (2011) & $\begin{array}{l}\text { Practitioners of } \\
\text { sharia banking PT. } \\
\text { Bank Perkreditan } \\
\text { Rakyat Syariah Niaga } \\
\text { Madani }\end{array}$ & $\begin{array}{l}\text { A qualitative } \\
\text { descriptive } \\
\text { approach by using } \\
\text { interviews and } \\
\text { filling a } \\
\text { questionnaire }\end{array}$ & $\begin{array}{l}\text { The results show that the system and prosecutor of } \\
\text { shariah pawnshops still use conventional pawning } \\
\text { bases. However, there are differences in the } \\
\text { financing system, the determination of } \\
\text { administrative costs, and the determination of } \\
\text { capital/interest lease rates based on the concept of } \\
\text { sharia ie ijara. }\end{array}$ \\
\hline $\begin{array}{l}\text { Paramitasari } \\
\text { (2012) }\end{array}$ & $\begin{array}{l}\text { The annual report of } \\
\text { Sharia Banks listed } \\
\text { on the Indonesia } \\
\text { Stock Exchange from } \\
2007 \text { to } 2009\end{array}$ & $\begin{array}{l}\text { Using the checklist } \\
\text { method based on } \\
\text { five themes and } \\
\text { eight dimensions } \\
\text { based on } \\
\text { Prasetyaningsih } \\
\text { (2010) research }\end{array}$ & $\begin{array}{l}\text { The results show that the annual report of sharia } \\
\text { banks from } 2007 \text { to } 2009 \text { has been close to the ideal } \\
\text { reporting standard. Thus, sharia commercial banks } \\
\text { have compliance with existing regulations relating to } \\
\text { reporting and disclosure. }\end{array}$ \\
\hline $\begin{array}{l}\text { Sukardi and } \\
\text { Wijaya (2013) }\end{array}$ & $\begin{array}{l}\text { The annual report of } \\
11 \text { sharia banks in } \\
\text { Indonesia in } 2012\end{array}$ & $\begin{array}{l}\text { Conducting an } \\
\text { exploratory survey } \\
\text { (field research) by } \\
\text { looking at the } \\
\text { information } \\
\text { disclosure annual } \\
\text { report of Sharia } \\
\text { Banks. }\end{array}$ & $\begin{array}{l}\text { The result of the research shows that the index of } \\
\text { BUS ethical identity ethics in Indonesia is ranged } \\
\text { from } 73.8 \% \text { to } 94 \% \text {. The highest index is owned by } \\
\text { Syariah Mandiri Bank and the lowest is Victoria } \\
\text { Sharia Bank. The results of this study indicate that it } \\
\text { is necessary a form of improvement in the reporting } \\
\text { of Sharia Banks to increase public confidence in the } \\
\text { existence of sharia banking in Indonesia. }\end{array}$ \\
\hline $\begin{array}{l}\text { Yuniwijayanti } \\
\text { (2014) }\end{array}$ & $\begin{array}{l}\text { The annual report of } \\
\text { Bank Muamalat and } \\
\text { Bank Syariah Mandiri }\end{array}$ & $\begin{array}{l}\text { A qualitative } \\
\text { approach with the } \\
\text { semiotic analysis } \\
\text { method }\end{array}$ & $\begin{array}{l}\text { The results showed that the annual report of } \\
\text { Muamalat and Syariah Mandiri Bank contained the } \\
\text { value of da'wah both text and images. The results } \\
\text { also show that BMI report gives more dakwah value } \\
\text { than BSM. }\end{array}$ \\
\hline $\begin{array}{l}\text { Pratiwi and } \\
\text { Chariri (2015) }\end{array}$ & $\begin{array}{l}\text { The annual report of } \\
\text { Bank Muamalat } \\
\text { Indonesia (BMI), } \\
\text { Bank Syariah Mandiri } \\
\text { (BSM), Bank Rakyat } \\
\text { Indonesia (BRI) Bank } \\
\text { Central Asia (BCA) } \\
\text { Syariah, dan Bank } \\
\text { Negara Indonesia } \\
\text { (BNI) Syariah. }\end{array}$ & $\begin{array}{l}\text { A qualitative } \\
\text { approach using an } \\
\text { interpretive } \\
\text { paradigm through } \\
\text { semiotic analysis }\end{array}$ & $\begin{array}{l}\text { The results of this study indicate that the annual } \\
\text { report of sharia banks contains religious values } \\
\text { contained in foto. The results also show that the } \\
\text { annual report of Sharia Banks provides an Islamic } \\
\text { reality that causes it to be different from the annual } \\
\text { report of other banks. }\end{array}$ \\
\hline Ningsih (2017) & $\begin{array}{l}\text { This research was } \\
\text { conducted on } \\
\text { syariah banking in } \\
\text { Kudus, Pati and } \\
\text { Jepara districts. The } \\
\text { sample of the } \\
\text { research was } 27 \\
\text { clients and } 7 \\
\text { managers of Bank. }\end{array}$ & $\begin{array}{l}\text { The method used } \\
\text { was field research }\end{array}$ & $\begin{array}{l}\text { The results of the study show that (1) Sharia bank } \\
\text { employees have applied friendship attitude to } \\
\text { customers, (2) Sharia bank employees have good } \\
\text { morals but were not responsible for complicated } \\
\text { issues, (3) bank employees have an individual } \\
\text { interest. }\end{array}$ \\
\hline
\end{tabular}




\section{Research Method}

This study aims to explore the Islamic values represented in the annual report of Bank Muamalat Tbk. The research approach used in this research was qualitative with the interpretive method. The interpretive method in this study is suitable for research purposes that are not intended to perform hypothesis testing but to do an interpretation of research data. The interpretive method used in this research is to analyze the data by using semiotic analysis.

The semiotic analysis used in this research is a differential semiotic analysis. Differential semiotic analysis is an analysis of data that focuses on meaning and sign. Differential semiotic analysis is an analytical method that focuses on the meaning that arises from the direct understanding of a text reader (Piliang, 2004). Analysis of semiotics in the study noticed four dimensions of meaning namely structural, contextual, denotative, and connotative.

Semiotic analysis of the annual sharia bank report is carried out on the narrative texts on the annual report. Semiotic analysis in this study is based on Charles Sanders Pierce's semiotic analysis which uses the triangles of meaning. The meaning triangle has three components namely sign, object, and interpretant. The following semiotic analysis technique model is applied in this study:

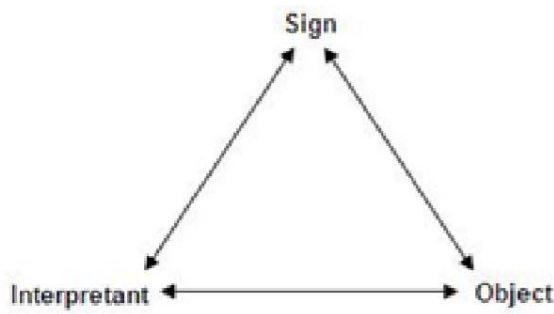

Figure 3 Triangle of Meaning

Source: Stone, 2000

This semiotic analysis is carried out in several stages. The first stage is to collect various sources of literature derived from the Qur'an, Al-Hadith, books, and the results of previous researches. The second stage is to link the signs in the narrative text of the Muamalat bank annual reports with various sources that have been collected. The third stage is to interpret the relationships that have been obtained from the previous stages.

The semiotic analysis as presented was used to analyze the annual report of Bank Muamalat Tbk from 2012 to 2016. The object of this study uses the annual reports of Bank Muamalat Tbk because Bank Muamalat Tbk is the first shariah bank operating in Indonesia. In addition, Bank Mumalat Tbk has received two awards that are the first rank for the number of assets more than 25 trillion and the first rank ranked first in the category of public company Indonesia-IV 2017 (APTI-IV-2017) (www.bankmuamalat.co.id). Secondary data in the form of annual reports of Bank 
Muamalat Tbk in 2012 until 2016 in this study obtained directly from the website of Muamalat Bank.

\section{Result and Discussion}

Muamalat Bank is the first syariah bank in Indonesia. The bank started operations from 1991 to the present. Muamalat Bank has been operating for approximately 26 years (1991-2017). Muamalat Bank became a public company in 1993. Thus, Muamalat Bank became the first public sharia bank in Indonesia. Muamalat Bank has a vision of "Being the best sharia bank and included in the top 10 banks in Indonesia which is regionally recognized" (AR, 2016: 56). The mission of Muamalat Bank is "To build a sustainable and sustainable Islamic financial institution with emphasis on entrepreneurship spirit based on prudent principles, Islamic and professional human resource excellence and innovative investment orientation to maximize value to all stakeholders" (AR, 2016: 56).

Muamalat Bank in its operational activities embraces the values of Professional, Modern, and Islami. These values are arranged in a circular form as shown in Figure 4.

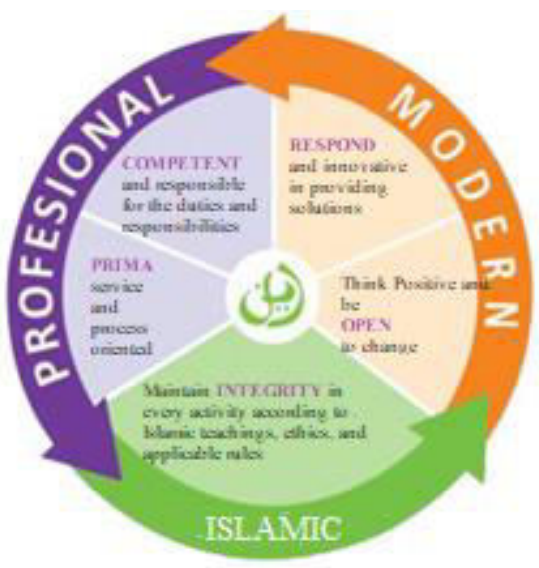

Figure 4 Values of Bank Muamalat Source: annual report 2016

The picture of the values adopted by Muamalat Bank in Figure 3 has its own purpose. A circle image with a clockwise direction means that Muamalat Bank follows sunatullah (solar system, tawaf rotation, and electron neutron). Colors applied in the circle have their own philosophy. The first color is green, where this color has the meaning of a universal value fresh in accordance with the image of the Islamic world. The second color is an orange color that has an attractive and dynamic meaning which is intended to show modernity. The third color is purple which has the meaning of maturity and establishment in accordance with the value of professionalism. The three circles then circled the "Dal-Yaa'-Nuun" logo. The logo has the meaning of "Ad Diin" which means religion and Madaniyah which means the lofty intentions of Muamalat Bank in creating justice and prosperity based on Islamic principles. 
Muamalat Bank issued mudharabah sub-sukuk sukuk amounting to Rp 200 billion in 2003. Sukuk from Muamalat Bank has a good ranking based on the rating result conducted by the Indonesian Securities Company (PEFINDO) as follows table 3.

Table 3 shows that the mudharabah sukuk rating of Muamalat Bank from 2012 to 2016 is rated A. The best sukuk rating of Muamalat Bank occurs in 2014 with an A + rating. Thus, the sukuk Muamalat Bank has good security for the investors. Share ownership in Muamalat Bank is currently dominated by Islamic Development Bank (IDB) with total ownership of $32.74 \%$, followed by the ownership of foreign business entities namely Boubyan Bank and Atwill Holdings Limited with ownership of 22 and 17, 91\% respectively. Muamalat Bank until 2016 has operated in Indonesia and Malaysia. The operational areas of Muamalat Bank during 2016 is briefly presented in table 4.

Table 3 Rating of Sukuk Bank Muamalat 2012-2016

\begin{tabular}{cc}
\hline Year & Sukuk Rating \\
\hline 2012 & id A \\
2013 & id A \\
2014 & id A+ \\
2015 & id A \\
2016 & id A- \\
\hline
\end{tabular}

Source: annual report 2016

Table 4 Operational Area of Bank Muamalat

\begin{tabular}{lcc} 
& Office Type & Number \\
\hline Main Branch & & 83 \\
Support Branch & & 202 \\
Cash Office & Total & 78 \\
& & 363 \\
\hline
\end{tabular}

Source: annual report 2016

Table 5 Affiliated Companies and Subsidiaries

\begin{tabular}{|c|c|}
\hline Company Name & Type of Services Provided \\
\hline \multicolumn{2}{|r|}{ Affiliated Companies } \\
\hline $\begin{array}{l}\text { Baitulmaal } \\
\text { Muamalat (bmm) }\end{array}$ & $\begin{array}{l}\text { Bank Muamalat's affiliated company responsible for giving services related to } \\
\text { the management of zakah, infaq, alms, and social funds. }\end{array}$ \\
\hline DPLK Muamalat & Bank Muamalat affiliated company that takes care of pension fund \\
\hline $\begin{array}{l}\text { Muamalat } \\
\text { Institute (MI) }\end{array}$ & $\begin{array}{l}\text { Bank Muamalat affiliated companies responsible for (1) the improvement of } \\
\text { the economic life of the community based on sharia principles, (2) developing } \\
\text { and socializing sharia financial institutions in Indonesia, (3) producing } \\
\text { professionals in the field of Islamic economics, (4) Developing, providing } \\
\text { socialization and education related to sharia economic system }\end{array}$ \\
\hline $\begin{array}{l}\text { PT Syarikat Takaful } \\
\text { Indonesia }\end{array}$ & $\begin{array}{l}\text { Affiliated companies from Bank Muamalat that provide insurance services } \\
\text { and financial plans based on sharia principles }\end{array}$ \\
\hline \multicolumn{2}{|r|}{ Subsidiaries } \\
\hline $\begin{array}{l}\text { Al ljarah Indonesia } \\
\text { Finance (ALIF) }\end{array}$ & $\begin{array}{l}\text { A subsidiary of Bank Muamalat which initially established financing services } \\
\text { for the business community, but in the end ALIF changed the business focus } \\
\text { on retail finance. }\end{array}$ \\
\hline
\end{tabular}

Source: annual report 2016 
Bank Muamalat Tbk as a syariah bank has affiliated companies and subsidiaries that provide sharia services. Sharia Banks have 4 affiliated companies and 1 subsidiary. A brief explanation of the affiliated companies and subsidiaries of Bank Muamalat Tbk is presented in table 5 .

\section{Always Saying Greetings, Praise, and Gratitude}

Religious values disclosed in the annual reports of Muamalat Bank from 2012 to 2016 are greetings and praises by saying thanks to Allah SWT. Both are always not forgotten to be delivered at the beginning of each report of the Sharia Supervisory Board, the main commissioner, and the board of directors. Here is greeting and acknowledgment delivered by the Sharia Supervisory Board in Muamalat Bank annual reports:

"Praise and gratitude be to Allah SWT for the blessings bestowed upon us all. Shalawat and greetings always devoted to the exemplary of people, Muhammad SAW" (AR, 2013:46)

"Alhamdulillah, with good cooperation of the Board of Directors and other work units involved in Bank Muamalat...." (AR, 2013:47)

"May Allah SWT be pleased and give strength to all of us to keep the spirit in exercising of this trust, and obtain blessings of the work we do." (AR, 2013:47)

"We are grateful that the Bank Muamalat in 2014 still able to maintain a good level of performance despite the challenges....." (AR, 2014:37)

"With a string of gratitude that God will continue to add and multiply what we try. But on the contrary, if we Kufr upon what has been acquired, His provision will apply. What we get today is a form of grace..." (AR, 2014:38)

"Assalamu'alaikum Warahmatullahi Wabarakatuh Alhamdulilahi Rabbil 'Aalamin, Wash Shalatu Was Salamu 'Ala Nabiyyina Muhammad, Wa 'Ala Aalihi Wa Shahbihi Wa Sallam, Amma Ba'du:" (AR, 2015:38)

"Praise and gratitude be to Allah SWT for the joys and blessings granted to us at all times...."(AR, 2015:38)

"We are off course should be grateful for what we have done, and for the results of such. Nevertheless, we should not stop to improve on what we have done.." (AR, 2015:40-41)

"May Allah SWT provides us with strength and a firm step all the way, to bless all our endeavour, and to unite our hearts in faithfulness to Him." (AR, 2015:41)

"All praise be to Allah SWT, for through His grace and guidance, we could cherish all His blessings and grow to be benevolent human beings. Shalawat and greetings to the 
esteemed prophet Muhammad SAW who has brought his people out to the bright age as it is today." (AR, 2016:25)

"May Allah always guides our step to realize the vision of being "The Best Sharia Bank and Top 10 Bank in Indonesia with Strong Regional Presence"." (AR, 2016:29)

Here is the acknowledgment and gratitude written by the board of commissioners of Muamalat Bank on the annual report 2012 to 2016:

"With praise and gratefulness to Allah SWT, I am pleased to..." (AR, 2013:52)

"If Allah wills it, with His guidance, Bank Muamalat would continue to make progress, grow and prosper along with its stakeholders, for the good of all concerned." (AR, 2013:57)

"With praise and gratitude to Allah SWT, I am pleased to...." (AR, 2015:44)

"All praise and gratitude to Allah SWT. May all His blessings and mercy always upon us. The Board of Commissioners is grateful that Bank Muamalat Indonesia has successfully...." (AR, 2016:33)

Here is the acknowledgment and gratitude written by the board of directors on the 2012-2016 annual reports:

"Thanks be to Allah SWT, Bank Muamalat managed to steer a clear course in managing the challenge of growth and was again successful in...." (AR, 2013:60)

"May the Blessings of Allah SWT be upon us always as we progress together" (AR,2013:67)

"Thanks be to the grace of Allah SWT, all ranks and file of Bank Muamalat continued to show a high spirit and dedication..." (AR, 2014:47)

"Praise be to Allah SWT, that Bank Muamalat Indonesia has been able to end the year 2015 with a satisfactory performance...." (AR, 2015:52)

"All praise and gratitude to Allah SWT upon His blessings and abundant mercy, Bank Muamalat Indonesia has successfully passed 2016 with a positive performance." (AR, 2016:41)

The use of greetings and acknowledgment to God in the welcoming part of the Sharia Supervisory Board, the board of commissioners, or the board of directors is a form of embodiment of Islamic values adopted by Muamalat Bank. The purpose of expressing gratitude is to show that the success of the business and operational activities carried out by Muamalat Bank cannot be separated from the help of Allah SWT. 
Muamalat Bank's annual reports from 2012 to 2016 shows the existence of phrasing gratitude to God Almighty who has helped in solving all kinds of problems, obstacles, and challenges faced in business to create the desired performance. This shows that Muamalat Bank indirectly communicates to the readers that the bank, in running business processes, is not always in easy and good condition. However, because of God's permission and assistance, every challenge and obstacle can be resolved. Actions taken by Muamalat Bank have been in accordance with Shariah Enterprise Theory stating that the entity should always be based on the Sharia to God Almighty. Muamalat Sharia Bank as an entity has shown that Muamalat Bank in doing business processes do not forget to put belief in God Almighty and realize that each attainment is obtained upon ridho of Allah SWT. This is in accordance with the word of God which is delivered in Sura An-Nisa 'verse 86 as follows:

"And when you are greeted with a greeting, greet (in return) with one better than it or (at least) return it (in a like manner). Indeed, Allah is ever, over all things, an Accountant"(QS. An Nisa': 86).

Greetings from DPS, the board of commissioners, and board of directors are always followed by the delivery of thanks to Allah SWT for every performance of the company. This gratitude is proof that Muamalat Bank realizes that all performances achieved by the company can not be separated from the permission of Allah SWT. Thus, Muamalat Bank has implemented what is described in SET. Triyuwono (2007) stated that SET should foster awareness of God for its users which ultimately obliges sunnatullah as the basis of sharia construction. Things done by Muamalat Bank in giving gratitude is in accordance with the words of Allah SWT in Surah Al-Baqarah verse 152 namely:

"Therefore remember Me, I will remember you. Give thanks to Me, and reject not Me." (Q.S. Al-Baqarah: 152)

\section{The Principles of Corporate Governance that reflect Islamic values}

Islamic values have significantly been revealed in the presentation of Muamalat Bank governance in the annual reports from 2012 to 2016. The explanation of Islamic values of governance in the annual report of Bank Muamalat developed from 2012 to 2016. The elicitation of Islamic values on the corporate governance in the 2012 and 2013 annual reports can be said to be simpler and simpler when compared to the elicitation in 2014, 2015, and 2016 reports. The elicitation of Islamic values on corporate governance in the annual report of 2012 and 2013 contained values related to "Muamalat Spirit". The following is an explanation of the Islamic values of corporate governance in the 2012 and 2013 annual reports:

"The core notion of Muamalat Spirit is a business horizon in which lies the GCG principles of transparency, accountability, responsibility, professional/independence, fairness, and concerns materialized through total devotion and obedience to Allah SWT." (AR, 2012:157, AR, 2013:184) 
The elicitation of the Islamic values on corporate governance explains that the application of the principles of transparency, accountability, responsibility, independence, fairness, and caring were done because of the obedience to Allah SWT. This is in accordance with the explanation of the Shariah Enterprise Theory (SET) which states that God is the main stakeholder of sharia entities. Thus, Muamalat Bank as a Shariah entity organizes its activities through good governance in light of the obedience to God.

The elicitation of the Islamic values on corporate governance of Bank Muamalat is more fully described in the annual reports published from 2014 to 2016. These reports explain that Bank Muamalat is basically managed by considering the principle of halal and taiyal. These principles are based on the word of Allah in Al-Qur'an Surah Al-Baqarah verses 168 and 188 and Al-A'raf verse 96 as follows:

"O mainkind, eat from whatever is on earth (that is) lawful and good and do not follow the footsteps of Satan. Indeed, he is to you a clear enemy." (Q.S.2:168)

"And do not consume one another's wealth unjustly or send it (in bribery) to the rulers in order that (they might aid) you (to) consume a portion of the wealth of the people in sin, while you know (it is unlawful). "(Q.S.2:188)

"And if only the people of the cities had believed and feared Allah, We could have opened upon them blessings from the heaven and the earth; but they denied (the messengers), so We seized them for what they were earning." (Q.S.7:96)

The verses explain that in doing its business, Muamalat Bank avoids activities and products that are not halal and tayib. Muamalat Bank as a sharia business entity is supposed to give priority to halal in carrying out its operational activities. Triyuwono (2007) states that all shari'ah business entities have the obligation to do business in halal ways. Muamalat Bank who has thought about the halal of products and business activities automatically also has to obey the command of Allah SWT not to follow the steps of satan and do not do vanity and sin. Muamalat Bank wants in business activities that do not only gain profit but also a blessing as a form of faith and devotion to Allah SWT.

The basic principles of halal and tayib embraced by Muamalat Bank resulted in all business activities undertaken to be completely protected from elements that are not kosher and not good. This is explained in the annual reports of Bank Muamalat from 2014 to 2016 that Muamalat Bank quoted the Qur'an and Hadith as the basis of its practices. The elements that are avoided by Muamalat Bank related to the principles of halal among others as follows:

a) Riba

The first element avoided by Muamalat Bank is usury. Muamalat Bank maintains that every product produced and activities undertaken shall avoid the element of usury. This 
is because usury is prohibited. Chair (2014) states that any transaction activity that has the element of usury is prohibited in Islamic teachings because the transaction has an element of exploitation to the debtor and may ruin the human intellect and morale. Thus, usury is one thing that is not in accordance with the principles of corporate governance adopted by Muamalat Bank. Muamalat Bank explicitly explains the avoidance of usury in the company by incorporating the word of Allah SWT in Surah AlBaqarah verse 275 as follows:

"Those who consume interest cannot stand (on the Day of Resurrection) except as one stand who is being beaten by Satan into insanity. That is because they say, "Trade is (just) like interest." But Allah has permitted trade and has forbidden interest. So whoever has received an admonition from his Lord and desists may have what is past, and his affair rests with Allah. But whoever returns to (dealing in interest or usury) - those are the companions of the Fire; they will abide eternally therein." (Q.S.2: 275)

b) Maysir

Maysir basically has a relationship with gharar because it also has an element of uncertainty. Maysir is banned in Islamic teachings because it has elements of qimar. The opinion of Ibn Taimiyah and Ibn Qayyim agree that maysir is forbidden because it can make a person neglectful of prayer, zikrullah, and hatred. Thus, Muamalat Bank in its annual reports from 2014 to 2016 declared its commitment to avoid unsuru maysir in the operational activities undertaken and the resulting products. The assertion was strengthened by using the words of Allah SWT in Sura Al-Maa-idah verses 90-91 as follows:

"O you who believed, indeed, intoxicants, gambling, (sacrificing on) stone alters (to other than Allah), and divining arrows are but defilement from the work of Satan, so avoid it that you may be successful. Satan only wants to cause between you animosity and hatred through intoxicants and gambling and to avert you from the remembrance of Allah and from prayer. So will you not desist?" (Q.S.5: 90-91)

c) Gharar

The gharar element in Mumalat Bank is another element that is avoided. Gharar means a form of doubt, trickery, or action in order to make other people's loss (Hosen, 2009). Muamalat Bank based on the principle of corporate governance adopted a will to always avoid products and operational activities that contain gharar. This is because gharar is forbidden in Islam. The affirmation related to the ban of gharar is presented by Muamalat Bank by reciting the word of Allah in Surah Al A'raaf verse 85 and Hadith of Muslim history as follows:

"...And do not deprive people of their due..." (QS. 7: 85).

"Indeed, the Prophet forbade than selling gharar (speculative and uncertainty)". (Narrated by Muslim) 
d) Zhulm

Zhulm is an element that is also avoided by Bank Muamalat because zhulm is a form of persecution. Thus, Muamalat Bank as a sharia entity rejects any operational activities and the resulting products that have zhulm element. This is confirmed by the Islamic teaching of zhum prohibition which comes from the word of Allah in Surah Al-Baqarah verse 193 as follows:

"Fight them until there is no (more) fitnah and (until) worship is (acknowledged to be) for Allah. But if they cease, then there is to be no aggression except against the oppressors." (Q.S.2:193).

\section{e) Tabdzir}

Tabdzir is the fifth element which is also avoided by Muamalat Bank in conducting its operational activities. Tabdzir has the meaning of being excessive (wasteful). Bank Muamalat avoids this tabdzir element based on the word of Allah on Surah Al-Isra 'verses 26-27 as follows:

"And give to families who close their rights, "And give the relative his right, and (also) the traveler, and do not spend wastefully. Indeed, the wasteful are brothers of the devils, and ever has Satan been to his Lord ungrateful." (Q.S.17: 26-27).

f) Risywah and Maksiyat

Risywah and Maksiyat at Muamalat Bank are also two things that are avoided. Risywah has the meaning of a bribe. Pujianto (2015) states that risywah is a form of grants intended for activities that are prohibited by Islam such as to take away the people's rights and to approve conceit. Risywah and Maksiyat are avoided in the operational activities and products in 2014 to 2016 annual reports of Muamalat Bank based on the word of Allah SWT as follows:

"And do not consume one another's wealth unjustly or send it (in bribery) to the rulers in order that (they might aid) you (to) consume a portion of the wealth of the people in sin, while you know (it is unlawful)."(Q.S.2: 188).

"... but Allah has endread to you the faith and has made it pleasing in your hearts and has made hateful to you disbelief, defiance and disobedience." (Al Hujurat / 49: 7).

The halal principles adopted by Muamalat Bank in carrying out its business and operational activities are then combined with the principle of tayib. The principle of tayib is embraced by Bank Muamalat with the aim that the business is done is a business that brings goodness to provide the added value of the halal elements in order to create security and welfare for society (AR, 2014: 146). The principle of tayib embraced by Muamalat Bank is insan and tawazun. Ihsan has the sense of doing or giving the best and avoiding destructive behavior, while tazwun is the balance between spiritual and 
material, exploration and conservation, financial and real sector, and risks and outcomes (AR, 2014: 146). The basic application of tayib principles by Muamalat Bank is based on several Surahs in the Qur'an presented in the annual report from 2014 to 2016 as follows:

"... And do good as Allah has done good to you. And desire not corruption in the land. Indeed, Allah does not like corrupters." (Q.S.28: 77)

"And the stars and trees prostrate. And the heaven He raised and imposed the balance. That you not transgress within the balance." (Q.S.55: 6-8).

The principles of halal and tayib adopted on the corporate governance of Muamalat Bank will ultimately lead to value-added to the ongoing business processes. This is because Muamalat Bank in conducting its business combines economic and spiritual value. Triyuwono (2007) explains that syari'ah value-added is the value-added of economic, mental, and spiritual that is obtained, processed, and distributed in a lawful way. Thus, the business concept applied in the form of corporate governance at Muamalat Bank at this time has been able to produce syari'ah value-added.

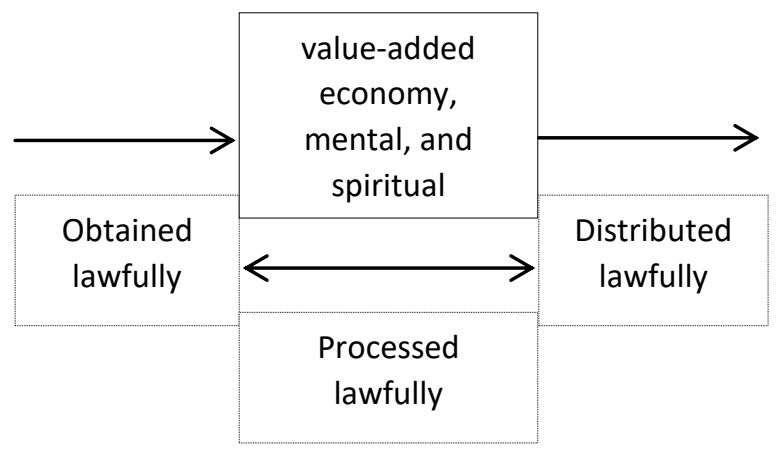

Figure 5 Shariah Added Value Concepts (Source: Triyuwono, 2007)

\section{The Islamic Values that can be adopted by the Conventional Principles of Corporate Governance}

Muamalat Bank as a Shari'a entity basically also continues to implement the five basic principles of Good Corporate Governance (GCG) that already existed. However, Muamalat Bank in its operational activities elaborated on the five principles with the suggestions drawn from the Qur'an and Al-Hadist. The elaboration made by Muamalat Bank ultimately resulted in the six principles of GCG. The six GCG principles adopted by Muamalat Bank is a concern. Muamalat Bank bases the implementation of these GCG principles with the surah in the Qur'an presented in the annual report from 2014 to 2016. The following are the principles of corporate governance applied by Muamalat Bank: 


\section{a) Transparency Principle}

The principle of transparency is the first principle applied by Bank Muamalat. This principle is a principle of Good Corporate Governance (GCG) which is applied generally in non-syari'ah entities. KNKG (2006:5) explains that the principle of transparency is run for the purpose of maintaining objectivity in doing business through the provision of material and relevant information to be accessible and understood by the interested parties. Muamalat Bank as a sharia entity in terms of the principle of transparency is a form of accountability to Allah SWT. It is because Muamalat Bank as a shari'ah entity makes Allah SWT as the center of responsibility for all actions. Shariah Enterprise Theory (SET) states that God is the center of all things (Triyuwono, 2007). Thus, the application of the transparency principle in Muamalat Bank shall be in accordance with the teaching of Islam. In this case, this principle is supported by the teaching at Surah An-Nisa verse 58 as follows:

"Indeed, Allah commands you to render trusts to whom they are due." (QS. An-Nisa:58)

\section{b) Accountability Principle}

The principle of accountability is a principle that requires accountability for undertaken business activities. KNKG (2006:5) states that a company must be able to be responsible for its performance fairly and transparently. This principle of accountability is related to the previous principle of transparency. The principle of accountability at Muamalat Bank itself is basically not only based on the conventional concept but also based on AlQur'an. This is because, in the Shariah entity, the most important stakeholder is God. The implementation of accountability principles at Muamalat Bank is based on several surahs as follows:

"Only those fear Allah, from among His servants, who have knowledge" (QS. Al Fathir: 28)

"Are those who know equal to those who do not know?" (QS Az-Zumar:9).

"Allah will raise those who have believed among you and those who were given knowledge, by degrees. And Allah is Acquainted with what you do."(QS Al Mujaadilah: 11)

\section{c) Responsibility Principle}

The third principle of GCG is responsibility. The principle of responsibility has a meaning that companies are obliged to comply with the prevailing legislation and to take responsibility for the society and the environment to create a long-term business continuity and recognition as a good corporate citizen (KNKG, 2006: 6). This principle fits the notion of Shariah Enterprise Theory which states that humans (indirect stakeholders) and nature are stakeholders in sharia business. Triyuwono (2007) explains that those who do not contribute at all and nature are included in the stakeholders of 
Sharia entities that are eligible to contribute. Muamalat Bank in carrying out the principle of responsibility is not only based on the conventional concept but also based on Al-Qur'an. The basis of applying the principle of accountability is teaching in Surah AlMudatsir paragraph 38 which was presented in the annual report as follows:

"Every soul, for what it has earned, will be retained." (QS. Al Muddatsir: 38)

d) Professional Principle

The professional principle is the same principle as the principle of independence applied in non-syariah entities. Professional at Muamalat Bank means having the competence, can be objective, free from the pressure of other parties (independent), free from conflict of interest and committed to the advancement of the company (AR, 2014: 150). The meaning of professional principle is broader when compared to the principle of independence prevailing in the GCG principles of non-sharia entities. The principle of independence in non-syariah GCG has a meaning that the company must be able to run independently and there is no domination and intervention from other parties (KNKG, 2006: 6). The professional principle at Bank Muamalat is based on Hadith's History of Abu Daud and Albany which was presented in 2014 to 2016 annual reports as follows:

"Whoever imitate a people, then it belonged to them" (HR Abu Daud)

"Truly Allah loves someone when doing any work, carried out in a professional manner (itqon)" (HR. Albany)

e) Fairness Principle

The fifth principle applied in the corporate governance of Muamalat Bank is the principle of fairness. The principle of fairness requires companies to always pay attention to the interests of shareholders and others based on the principle of fairness and equality (KNKG, 2006: 7). This indicates that not all stakeholders must be fulfilled in their portions. Muamalat Bank in 2014 to 2016 annual reports emphasized that the principle of fairness and equality adopted is fair behavior and good deeds. This is based on the word of Allah in Surah An-Nahl verse 90 and Surah An Nisa verse 135 which was presented in the annual reports as follows:

"Indeed, Allah orders justice and good conduct"(QS.An.Nahl: 90).

"O you who believed, be persistently standing firm in justice, witnesses of Allah, even if it be against yourselves or parents and relatives...." (Qs. An Nisa: 135)

\section{f) Caring Principle}

The last principle in the corporate governance of Muamalat Bank is the principle of caring. This principle is different from the principles applied in non-syariah entities. This 
principle arises basically due to the adopted concept of sharia. The concept of sharia causes a balance that raises awareness not only on the interests of the individual but also on the other sides (Triyuwono, 2007). The principle is based on the word of Allah SWT in Surah Al-Maidah paragraph 2 presented in 2014 to 2016 annual reports as follows:

"And cooperate in righteousness and piety, but do not cooperate in sin and aggression." (QS. Al- Maidah: 2)

\section{Islamic Values in Corporate Social Responsibility}

The latest Islamic values were also found in the reporting section of Muamalat Bank Corporate Social Responsibility (CSR) activities. Based on the annual reports of 2012 to 2016, Muamalat Bank CSR activities emphasized the Islamic religious values. The social activities are presented in table 6 .

Table 6 Social Activities with Islamic Values

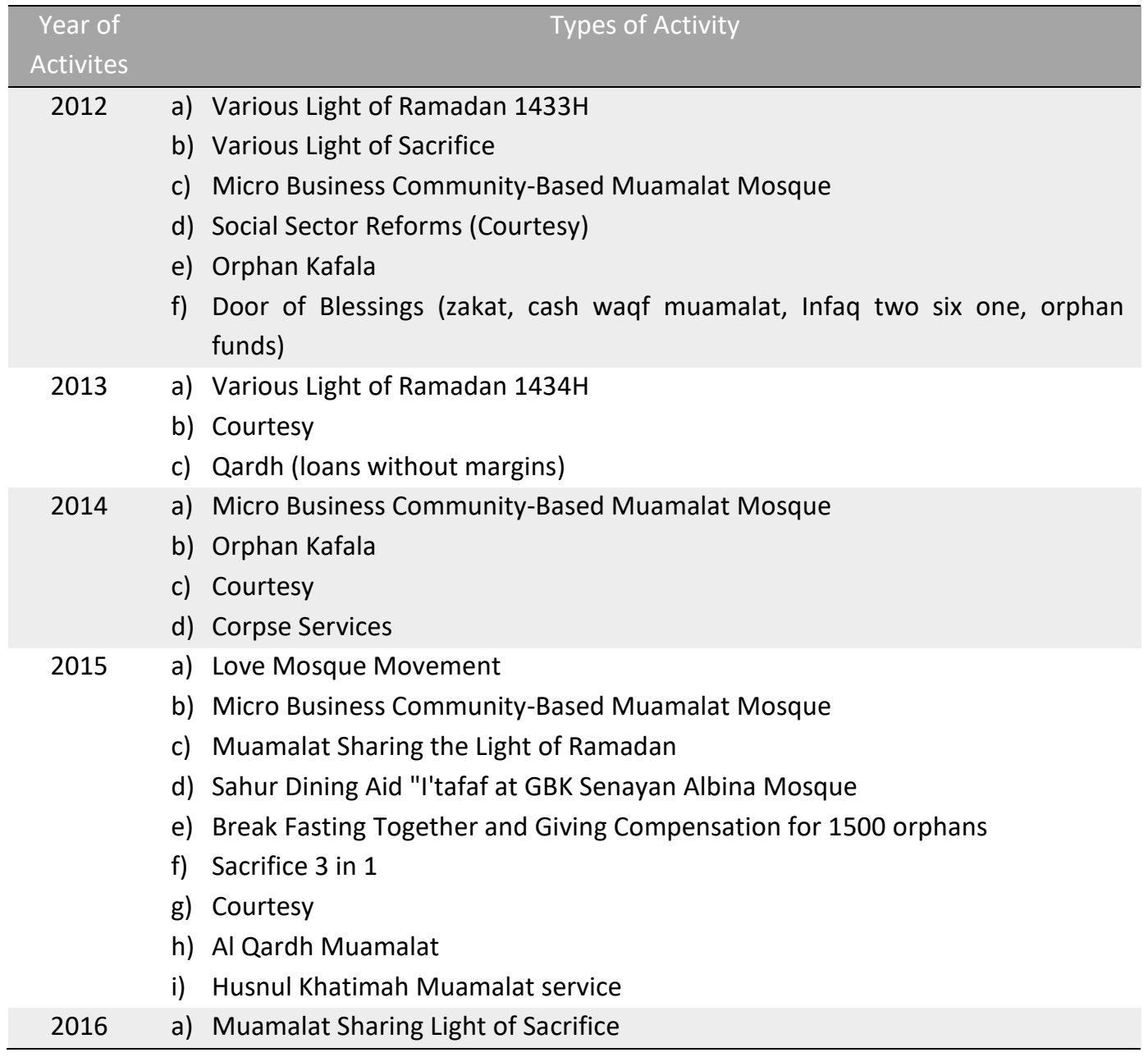

Source: data processed 
The CSR activities conducted by Muamalat Bank in table 6 show a difference between them and those conducted by non-Sharia entities. In terms of reporting, the CSR in Islamic entity is commonly known as Islamic Social Reporting (ISR). Nugraheni and Giuliani (2017) state that Islamic Social Reporting (ISR) is an extension of the social report that has embraced the Islamic values in it. This is proven by the existence of religious social activities undertaken by Muamalat Bank. Table 6 shows that the social activities undertaken by Muamalat Bank is different from social activities undertaken by non-Sharia entities.

Social activities undertaken by Muamalat Bank is basically an obligation to guarantee that the business activities are devoted to God Almighty. Islamic Social reporting is a form of accountability addressed to Almighty God and the society with the aim to enhance the transparency of business activities through the delivery of the right information and concerns about the spiritual needs of the Islamic investors (IAEI, 2015). Thus, the proposed ISR in the annual reports was because the stakeholders of Sharia banks consist of three parties namely God, man, and nature.

\section{Conclusion}

This article aims to know and understand the reality of Islamic values represented in the annual reports of Muamalat Bank from 2012 to 2016. The results showed that the annual reports of Muamalat Bank from 2012 to 2016 had Islamic values. The Islamic values were found most frequently in the annual reports of Muamalat Bank from 2014 to 2016. They were included in the Sharia Supervisory Board (DPS) report, the board of commissioner report, the board of directors, corporate governance information, and information related to Corporate Social Responsibility (CSR). Each of the early parts of the annual reports revealed that all performances achieved by the bank are ridho and help from Allah SWT because any existing business processes in this bank might not always go well. The Islamic values represented in the annual reports of Muamalat Bank proves that the operational activities of Islamic business were run in accordance with the teaching of Islam and believed that God is the main stakeholders. Thus, Muamalat Bank is expected to always be consistent in carrying out all business activities based on Islamic values as what has been represented in the annual reports. A good practice of Islamic values is finally expected to result in the meaningful added value of sharia.

The results of this study can be accepted with regard to some limitations. The limitations in this article need to be considered for future research as a basis for improvement. The first limitation is in terms of its sources which is limited in support of the theory related to the phenomenon of Islamic values on the disclosure of information in the annual reports. As a consequence, it leads to difficulty in reviewing, evaluating, and addressing the Islamic values in in-depth. In this case, further researches are necessary to explore more sources that can support an in-depth discussion of Islamic values in the annual report sharia banking. The next limitation is in relation to methodologies that are so far similar to other existing studies. Further researches will be necessary to develop 
methodologies to investigate the Islamic values represented in the annual report of sharia banking.

\section{References}

Afdal, A.M.N. (2011). Studi Pemahaman Nilai-Nilai Syariah pada Praktisi Perbankan Syariah (Studi pada PT. Bank Perkreditan Rakyat Syariah Niaga Madani). Undergraduate Thesis, Universitas Hasanuddin, Makassar. Retrieved from http://repository.unhas.ac.id/handle/123456789/1334?show=full

Alharbi, A. (2015). Development of the Islamic Banking System. Journal of Islamic Banking and Finance, 3(1), 12-25. https://doi.org/10.15640/jibf.v3n1a2

Amerieska, S. Irianto, G., \& Affandy, D.P. (2012). Akuntabilitas pada Baitul Maal Wal Tamwil Ditinjau dari Prespektif Shari'ate Enterprise Theory. Jurnal Ekonomi \& Kenangan Islam, 2(1): 27-39. Retrieved from http://journal.uii.ac.id/JEKI/article/download/8766/7445

Ascarya \& Yumanita, D. (2005). Bank Syariah: Gambaran Umum. Jakarta: Pusat Pendidikan dan Studi Kebanksentralan (PPSK) Bank Indonesia. Retrieved from https://www.researchgate.net/profile/Ascarya Ascarya/publication/304783232 Ban k Syariah Gambaran Umum/links/577aa9b408ae355e74f073cc.pdf

Bank Indonesia. (1992). Undang-Undang Republik Indonesia Nomor 7 tentang Perbankan. Retrieved from https://www.bphn.go.id/data/documents/92uu007.pdf

Bank Indonesia. (1998). Undang-Undang Republik Indonesia Nomor 10 tentang Perubahan atas Undang-Undang No. 7 Tahun 1992 tentang Perbankan. Retrieved from https://www.bphn.go.id/data/documents/98uu010.pdf

Bank Indonesia. 2008. Undang-Undang Republik Indonesia Nomor 21 tentang Perbankan Syariah. Retrieved from https://www.ojk.go.id/waspadainvestasi/id/regulasi/Pages/Undang-Undang-Nomor-21-Tahun-2008-TentangPerbankan-Syariah.aspx

Bank Muamalat. (2013). Laporan Tahunan 2012. Retrieved from: http://www.bankmuamalat.co.id/hubungan-investor/laporan-tahunan

Bank Muamalat. (2014). Laporan Tahunan 2013. Retrieved from: http://www.bankmuamalat.co.id/hubungan-investor/laporan-tahunan

Bank Muamalat. (2015). Laporan Tahunan 2014. Retrieved from: http://www.bankmuamalat.co.id/hubungan-investor/laporan-tahunan

Bank Muamalat. (2016). Laporan Tahunan 2015. Retrieved from: http://www.bankmuamalat.co.id/hubungan-investor/laporan-tahunan

Bank Muamalat. (2017). Laporan Tahunan 2016. Retrieved from: http://www.bankmuamalat.co.id/hubungan-investor/laporan-tahunan

Chachi, A. (2005). Origin and Development of Commercial and Islamic Banking Operations. Journal of King Abdulaziz University-Islamic Economics, 18(2), 3-25. https://doi.org/10.4197/islec.18-2.1

Chair, W. (2014). Riba dalam Prespektif Islam dan Sejarah. Iqtishadia. 1(1): 99-112. https://doi.org/10.19105/iqtishadia.v1i1.368

Haified, H. \& Nasir, M. (2013). Lembaga Kenangan Syariab: Teori dan Penilitian Empiris. Makassar: PT. Umitoha Ukhuwah Grafika

Hosen, N. (2009). Analisis Bentuk Gharar dalam Transaksi Ekonomi. Al-Iqtishad, 1(1): 53-64. https://doi.org/10.15408/aiq.v1i1.2453 
Ikatan Akuntan Indonesia (IAI). (2009). Kerangka Dasar Penyusunan dan Penyajian Laporan Keuangan Syariah. Jakarta: Dewan Standar Akuntansi Keuangan Ikatan Akuntan Indonesia. Retrieved from http://iaiglobal.or.id/v03/tentang iai/dsak

Komite Nasional Kebijakan Governance (KNKG). (2006). Pedoman Umum Good Corporate Governance Indonesia. Retrieved from http://www.knkgindonesia.org/download

Muhammad, R. (2009). Studi Evaluatif terhadap Perbankan Syariah. Jurnal Akuntansi dan Auditing Indonesia, 13(2): 189-209. Retrieved from https://journal.uii.ac.id/JAAI/article/download/2269/2070

Ningsih, E.R. (2017). Studi Eksplorasi Penerapan Etika Bisnis pada Perbankan Syari'ah di Indonesia. Iqtishadia, 10(1): 156-177. Retrieved from https://media.neliti.com/media/publications/91422-ID-studi-eksplorasi-penerapanetika-bisnis.pdf

Nugraheni, P. (2012). Kebutuhan dan Tantangan Audit Syariah dan Auditor Syariah. Jurnal Ekonomi \& Keuangan Islam, 2(1):76-88. Retrieved from https://journal.uii.ac.id/JEKI/article/view/8770

Nugraheni, P. \& Yuliani, R. D. (2017). Mekanisme Corporate Governance dan Pengungkapan Islamic Social Reporting pada Perbankan Syariah di Indonesia dan Malaysia. Iqtishadia, 10(1):130-155. Retrieved from https://media.neliti.com/media/publications/90435-ID-none.pdf

Otoritas Jasa Keuangan. (2017). Statistik Perbankan Syariah 2017. Jakarta

Paramitasari, R. (2012). Islamic Corporate Identity in The Practice of Annual Report Disclosure Sharia Bank. Assets: Jurnal Akuntansi dan Pendidikan, 1(1): 34-44. https://doi.org/10.25273/jap.v1i1.538

Piliang, Y.A. (2004). Semiotik Teks: Sebuah Pendekatan Analisis Teks. Mediator, 15(2): 189198. Retrieved from https://ejournal.unisba.ac.id/index.php/mediator/article/view/1156

Prasetyaningsih, N. U., \& Prakosa, N. I. (2010). Islamic Corporate Identity dalam Praktik Pengungkapan Laporan Tahunan Bank Syariah. Retrieved from http://repository.ut.ac.id/2130/

Pratiwi, R.N. \& Chariri, A. (2015). Akuntansi Sebagai Realitas Ekonomi dan Keagamaan: Mengungkap Nilai-Nilai Religus Melalui Foto dalam Laporan Tahunan Perbankan Syari'ah. Diponegoro Journal of Accounting, 4(3): 1-15.

Stone, R. A Semiotic Analysis of Four Designer Clothing Advertisement, htttp://www.aber.uc.uk/media/Students/rbs9701.html

Sukardi, B. \& Wijaya, T. (2013). Corporate Ethical Identity Perbankan Syariah di Indonesia. Jurnal Tsaqafah, 9(2): 337-356. https://doi.org/10.21111/tsaqafah.v9i2.56

Triyuwono, I. (2007). Mengangkat "Sing Liyan" untuk Formulasi Nilai Tambah. Simposium Nasional Akuntansi X. Universitas Hasanuddin Makassar 26-28 Juli 2007

Yuniwijayanti, R. (2014). Ekspolrasi Nilai-Nilai Dakwah dalam Laporan Tahunan Perbankan Syariah: Analisis Semiotik pada Laporan Tahunan Bank Muamalat Indonesia dan Bank Syariah Mandiri. Unpublished Undergraduate Thesis, Universitas Diponegoro, Semarang. Retrieved from http://eprints.undip.ac.id/42863/ 